bioRxiv preprint doi: https://doi.org/10.1101/2021.02.19.432036; this version posted February 22, 2021. The copyright holder for this preprint (which was not certified by peer review) is the author/funder, who has granted bioRxiv a license to display the preprint in perpetuity. It is made available under aCC-BY 4.0 International license.

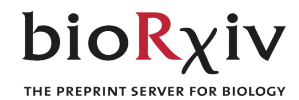

bioRxiv, 2021, 1-11

Preprint

Short title: Deep rooting and abiotic stress tolerance in switchgrass

\title{
Interactions among rooting traits for deep water and nitrogen uptake in upland and lowland ecotypes of switchgrass (Panicum virgatum L.)
}

\author{
Marcus Griffiths ${ }^{1, \dagger}$, Xueyan Wang ${ }^{1}$, Kundan Dhakal ${ }^{1}$, Haichao Guo ${ }^{1}$, Anand \\ Seethepalli ${ }^{1}$, Yun Kang ${ }^{1}$ and Larry M. York ${ }^{1}{ }^{*}$
}

\author{
${ }^{1}$ Noble Research Institute, LLC, 2510 Sam Noble Parkway, Ardmore, OK 73401, USA \\ ${ }^{\dagger}$ Current address: Donald Danforth Plant Science Center, St. Louis, MO 63132 \\ * To whom correspondence should be addressed. E-mail: lmyork@noble.org
}

\begin{abstract}
Plant phenotypic plasticity in response to nutrient and water availability is an important adaptation for abiotic stress tolerance. Roots intercept water and nutrients while foraging through soil searching for further resources. Substantial amounts of nitrate can leach into groundwater; yet, little is known about how deep rooting affects this process. Here, we phenotyped root system traits and deep ${ }^{15} \mathrm{~N}$ nitrate capture across $1.5 \mathrm{~m}$ profiles of solid-media using tall mesocosms in switchgrass (Panicum virgatum L.), a cellulosic bioenergy feedstock. Root and shoot biomass, photosynthesis and respiration, and nutrient uptake traits were quantified in response to a water and nitrate stress factorial experiment in the greenhouse for switchgrass upland (VS16) and lowland (AP13) ecotypes. The two switchgrass ecotypes shared common plastic abiotic responses to nitrogen $(\mathrm{N})$ and water availability and yet showed genotypic differences for root and shoot traits. A significant interaction between nitrogen and water stress for axial and lateral root traits represents a complex and shared root development strategy for stress mitigation. Deep root growth and ${ }^{15} \mathrm{~N}$ capture were found to be closely linked to aboveground growth. Together, these results represent the wide genetic pool of switchgrass and that deep rooting promotes nitrate capture, plant productivity, and sustainability.
\end{abstract}

Key words: Deep rooting; water; nitrogen; abiotic stress; plasticity; partitioning; strategies; tolerance; switchgrass; mesocosm

\section{Introduction}

The root system of a plant serves multiple important roles, ${ }_{14}$ from structural stability in the soil to resource foraging for 15 water and nutrients. The spatial and temporal arrangement ${ }_{16}$ of roots in the soil (broadly referred to as root system ar- 17 chitecture) can greatly affect the interception and subsequent ${ }_{18}$ uptake of soil resources. Root growth and development are 19 highly responsive to both the environmental conditions and the 20 plant's resource requirements. Greater knowledge of this dy- 21 namic process in plants is important to characterize ecological ${ }_{22}$ adaptations and breed for beneficial adaptations enabling more ${ }_{23}$ resource-efficient plant varieties.

Water and nitrogen $(\mathrm{N})$ are the two most frequently limiting resources in agriculture, affecting plant growth and yield. Both water and nitrate- $\mathrm{N}$ are highly mobile in the soil profile, which means plants have a limited opportunity to acquire these resources. Plant adaptive responses help mitigate such abiotic stresses through changes in growth and development in response to the plant's nutritional requirements and the environment. Deep rooting is regarded as a beneficial trait for plant productivity and abiotic stress mitigation by expanding the soil volume explored, effectively increasing soil resources available to the plant. It increases the soil volume explored and 
bioRxiv preprint doi: https://doi.org/10.1101/2021.02.19.432036; this version posted February 22, 2021. The copyright holder for this preprint (which was not certified by peer review) is the author/funder, who has granted bioRxiv a license to display the preprint in 2 bioRxiv, 2021 perpetuity. It is made available under aCC-BY 4.0 International license.

\section{Highlight}

Two main ecotypes of switchgrass have both shared and different root responses to varying water and nitrogen conditions, with deep rooting shown to be closely linked to aboveground growth.

consequently soil resources available to the plant (reviewed by 84 Thorup-Kristensen et al., 2020). Increased root length at depth 85 also enables plants to capture water and nitrate that otherwise would be lost through deep soil-water movement and leaching. Deep rooting traits in turn can reduce the environmental damage caused by the leaching of nutrients into groundwater (Foulkes et al., 2009; Kumar and Goh, 2002). However, roots are challenging to phenotype and evaluate quantitatively as they are the hidden half of the plant, and relatively little is ${ }_{88}$ known about root growth, nutrient capture, and root longevity ${ }_{89}$ of perennial crops. At present, root evaluation at depth is of- ${ }_{90}$ ten conducted by soil coring methods in the field, with subse- ${ }_{9}$ quent root washing and image analysis or qPCR for DNA abun- ${ }_{92}$ dance used for quantifying root length or mass (Kristensen and Thorup-Kristensen, 2004; Heuermann et al., 2019), stable iso- ${ }_{94}$ tope tracing (Ehleringer and Dawson, 1992; Chen et al., 2018), 95 or under more controlled setups using large rhizotrons (Nagel 96 et al., 2012; Ytting et al., 2014) or large mesocosms (Guo and ${ }_{97}$ York, 2019; Saengwilai et al., 2014; Zhan et al., 2015).

Switchgrass (Panicum virgatum L.) is a $\mathrm{C} 4$, warm-season 99 perennial grass that is native to North America and has an ${ }^{100}$ extensive and deep root system with recorded rooting depths ${ }^{101}$ of $330 \mathrm{~cm}$ in field trials ( $\mathrm{Ma}$ et al., 2000). As with many ${ }^{102}$ prairie grasses, switchgrass develops rhizomes which are un-103 derground, stem-derived organs that provide plants with the ${ }^{104}$ ability to grow clonally and regrow after disturbance in the soil ${ }^{105}$ (Weaver, 1954; Freschet et al., 2020). Switchgrass is found 106 across a diverse geographical range from Canada to Central ${ }^{107}$ America and has a promising utility as a cellulosic bioenergy ${ }^{108}$ feedstock. Switchgrass has low input requirements, so is ideal ${ }^{109}$ for growth on marginal lands. In addition, switchgrass is re-110 ported to provide ecosystem services with an enhancement of 11 soil organic matter, reduction in soil erosion, and associative $\mathrm{N}{ }^{112}$ fixation (Lai et al., 2018; Gilley et al., 2000; Roley et al., 2019). ${ }^{113}$ Switchgrass can be divided into two main ecotypes, upland and lowland, which are estimated to have diverged 0.7-1.0 million years ago (Morris et al., 2011). The ecotype divergence in switchgrass is hypothesized to be through climatic-associated adaption with the upland ecotype found in more northern lati- ${ }^{11}$ tudes and across drier precipitation gradients than the lowland ${ }^{116}$ ecotype (Lovell et al., 2021). The upland ecotype has also been ${ }^{11}$ found to be generally smaller with a greater number of tillers ${ }^{118}$ and an earlier flowering time (Milano et al., 2016; Singer et al., ${ }^{19}$ 2019). As the ecotypes are diverse, each has its own benefi $-^{120}$ cial breeding potential with different environmental adaptation ${ }^{12}$ and pathogen resistance (Milano et al., 2016). For switchgrass ${ }^{122}$ adoption as a bioenergy feedstock, the biomass yield will have ${ }^{123}$ to be maximized in a sustainable manner, which requires $\mathrm{a}^{124}$ greater understanding of the interactions among environment, ecotype, and soil dynamics (Lemus et al., 2014).

In-depth characterization of the physiological and morphological differences of the main switchgrass ecotypes is important to understand the functional adaptations to resource cap- ${ }^{-125}$ ture and to characterize the differences in abiotic stress toler- ${ }_{-126}$ ance. The aim of this study was to characterize and compare ${ }_{127}$ the root systems of the representative upland and lowland eco- ${ }_{128}$ types of switchgrass and the root adaptive responses to water ${ }_{129}$ and nitrogen stress. To achieve this, we set up a tall mesocosm ${ }_{130}$ greenhouse study with water and nitrogen factorial stresses us- ${ }^{-131}$ ing clones of representative upland and lowland cultivars and ${ }_{132}$ evaluated the vertical distribution of the root system across 150 $\mathrm{cm}$ depth along with other physiological characteristics.

\section{Materials and methods}

\section{Plant materials and experiment design}

Clones derived from two contrasting genotypes of switchgrass, $\mathrm{AP} 13$ and VS16, were used in this study to represent the two ecotypes. AP13 is a clone derived from the lowland cultivar 'Alamo', which is the source of the switchgrass reference genome, and VS16 is a clone derived from the upland cultivar 'Summer'. Mapping populations have been derived from crossing these two ecotypes (Milano et al., 2016), which highlights their importance for switchgrass research. Recently-emerged tillers from well-established plants were pulled apart by hand and one tiller consisting of a small shoot and root system was transplanted per mesocosm at the start of the experiment. The mesocosm experiment was conducted in a greenhouse from $30^{\text {th }}$ September 2019 to $22^{\text {nd }}$ January 2020 at the Noble Research Institute, LLC, Ardmore, OK, USA ( $34^{\circ} 11^{\prime} \mathrm{N}, 97^{\circ} 5^{\prime} \mathrm{W}$; elevation $268 \mathrm{~m}$ ). The greenhouse conditions were set to a $15 / 7$ $\mathrm{h}$ day/night cycle at $24 / 21^{\circ} \mathrm{C}$ with an average photosynthetically active radiation (PAR) reading of $150 \mathrm{~mol} \mathrm{~m}^{2} \mathrm{~s}^{1}$ provided with supplemental lighting. Monthly averages for greenhouse conditions are provided in Table S1. The mesocosm experiment was arranged as a randomized complete block design, replicated five times with a $2 \times 2 \times 2$ factorial arrangement of treatments. The factors were two levels of $\mathrm{N}$ supply (high- and low-N, HN and LN), two watering levels (well-watered and drought-stressed, WW and DS), and two ecotypes (upland and lowland). The treatment combinations are hereafter referred to as HN/WW, LN/WW, HN/DS, and LN/DS.

\section{Mesocosm preparation}

The media mixture used in the mesocosm study mimics mineral soil and consisted of sand, vermiculite, and perlite which was mixed using a cement mixer. By volume basis, the mixture constituents used were $50 \%$ medium size $(0.3-0.5 \mathrm{~mm})$ premium sand (Quikrete, GA, USA), 40\% premium grade vermiculite (Sun Gro Horticulture, Agawam, MA, USA), and $10 \%$ perlite (Ambient Minerals, AR, USA). The gravimetric water content of the media mixture at mesocosm filling and before watering was $2.5 \%$, as determined by oven-drying $20 \mathrm{~g}$ of media at $105^{\circ} \mathrm{C}$ for 48 hours (Equation 1) (Rowell, 1994).

$$
\Theta g=\frac{\text { (Wet soil mass }- \text { Dry soil mass) }}{\text { Dry soil mass }}
$$

Media N levels of the starting media mixture before the nutrient application was determined to be $0.11 \mathrm{mM}$ by ion chromatography. Twenty grams of media were first added to 50 $\mathrm{mL}$ of $0 \mathrm{~N} \mathrm{1/2}$ Hoagland's solution (detailed below) and then shaken for $30 \mathrm{~min}$ at $150 \mathrm{rpm}$. After shaking, the sample was left undisturbed for five minutes for the particles to settle, and then five $\mathrm{mL}$ of the supernatant was centrifuged at 10,000 rpm for five minutes in a $15 \mathrm{~mL}$ falcon tube. The ion concentrations 
bioRxiv preprint doi: https://doi.org/10.1101/2021.02.19.432036; this version posted February 22, 2021. The copyright holder for this preprint (which was not certified by peer review) is the author/funder, who has granted bioRxiv a license to display the preprint in perpetuity. It is made available under aCC-BY 4.0 International license.

of the collected supernatant samples were then determined us- -168 ing a Thermo Scientific ICS-5000+ ion chromatographic sys $\neg 69$ tem using $500 \mathrm{~L}$ of the sample (Thermo Fisher Scientific, MA, 170 USA).

The mesocosms used in this study consisted of polyvinyl chloride (PVC) pipe cut to size $15.24 \mathrm{~cm}$ [internal diameter] $\times$ $152.4 \mathrm{~cm}$ [height] with a flat-bottom PVC cap (IPS Corporation, Collierville, TN, USA), and lined with a seamless heavy-duty (6 Mil) poly tubing (Uline, WI, USA) (Fig. 1A). The mesocosms were evenly filled from the top of the column with $28 \mathrm{~L}$ of the air-dry media resulting in an approximate bulk density of $1.1 \mathrm{~g}$ $\mathrm{cm}^{-3}$. Three days before transplanting, the mesocosms were irrigated from the top with six L of nutrient solution. Half of the mesocosms received a zero $\mathrm{N} 1 / 2$-strength Hoagland's solution for $\mathrm{LN}$ treatment and the other received a high $\mathrm{N} 1 / 2$-strength Hoagland's solution (6 mM NO3-N) for HN treatment. The high $\mathrm{N}$ solution composed of (in $\mu \mathrm{M}) 500 \mathrm{KH}_{2} \mathrm{PO}, 5700 \mathrm{KNO}_{3}$, $300 \mathrm{NH}_{4} \mathrm{NO}_{3}, 2000 \mathrm{CaCl}_{2}, 1000 \mathrm{MgSO}_{4}, 46 \mathrm{H}_{3} \mathrm{BO}_{3}, 7 \mathrm{ZnSO}_{4}{ }_{7} \mathrm{H}_{2} \mathrm{O}$, $9 \mathrm{MnCl}_{2} \cdot{ }_{4} \mathrm{H}_{2} \mathrm{O}, \quad 0.32 \mathrm{CuSO}_{4} \cdot{ }_{5} \mathrm{H}_{2} \mathrm{O}, \quad 0.114\left(\mathrm{NH}_{4}\right)_{6} \mathrm{Mo}_{7} \mathrm{O}_{24} \cdot{ }_{4} \mathrm{H}_{2} \mathrm{O}$, and $150 \mathrm{Fe}(\mathrm{III})-\mathrm{EDTA}\left(\mathrm{C}_{10} \mathrm{H}_{12} \mathrm{~N}_{2} \mathrm{NaFeO}_{8}\right)$. For the zero $\mathrm{N}$ solution, $\mathrm{KNO}_{3}$ and $\mathrm{NH}_{4} \mathrm{NO}_{3}$ was replaced with $5700 \mathrm{KCl}$.

\section{Mesocosm greenhouse growth conditions}

One tiller of a clone was transplanted per mesocosm; the mesocosms were watered with the respective nutrient solution three times a week with $200 \mathrm{~mL}$ added from the top at each watering. ${ }_{177}$ After four weeks of growth in the mesocosms, half of the meso- ${ }_{178}$ cosms were subjected to drought-stress receiving no more wa- ${ }_{179}$ tering for the rest of the experiment. The well-watered meso- ${ }_{180}$ cosms continued to be watered three times a week with $200_{181}$ $\mathrm{mL}$ double-deionized water instead of nutrient solution. At the ${ }_{182}$ end of the experiment, the drought-stressed mesocosms had $\mathrm{a}_{183}$ gravimetric water content ranging from $16 \%$ in the first $30 \mathrm{~cm}_{184}$ layer to $28 \%$ in the deepest $30 \mathrm{~cm}$ layer (Table 1 ). The gravimet ${ }_{185}$ ric water content of the well-watered mesocosms ranged from ${ }_{186}$ $27 \%$ in the first $30 \mathrm{~cm}$ layer to $34 \%$ in the bottom layer (Table ${ }_{187}$
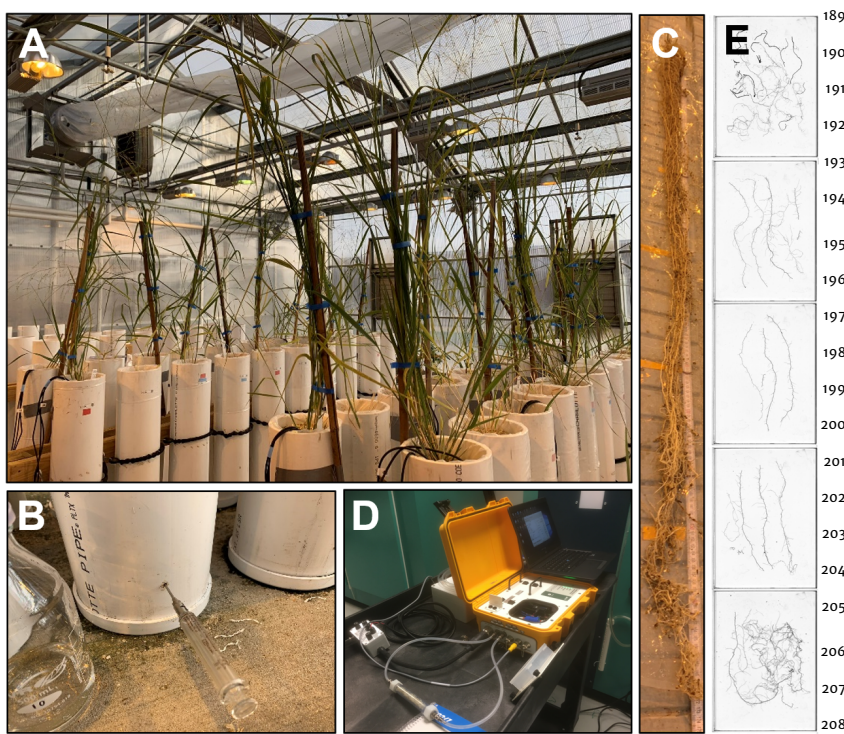

Figure 1. Switchgrass mesocosm experiment design. (A) Upland and lowland ${ }^{209}$ ecotypes were grown in tall mesocosms under a factorial nitrogen and water stress conditions HN/WW, LN/WW, HN/DS, LN/DS. (B) ${ }^{15} \mathrm{~N}$ was injected into ${ }^{21}$ the deepest layer of the mesocosms 24 hours before the shoot material was har- ${ }^{212}$ vested. (C) The medium was carefully washed away, and the root system was ${ }^{213}$ cut into $30 \mathrm{~cm}$ layers which were used for (D) instantaneous root respiration 214 analysis using an LI-8100 with custom chambers, and (E) root feature deter- ${ }_{215}$ mination by root scanning and image analysis using RhizoVision Explorer.
1.). The water stress was applied over a depth gradient. Averaged across the whole mesocosm the gravimetric water content for the water-stressed and well-watered mesocosms were $23 \%$ and $29 \%$, respectively.

Table 1. Gravimetric water content (\%) of mesocosms determined at the end of the greenhouse study.

\begin{tabular}{lcc}
$\begin{array}{l}\text { Soil horizon } \\
\text { (cm depth) }\end{array}$ & \multicolumn{2}{l}{ Mesocosm treatment } \\
\hline & Well-watered & Drought-stressed \\
\hline $0-30$ & 27.28 & 16.47 \\
$30-60$ & 26.52 & 23.26 \\
$60-90$ & 27.36 & 19.80 \\
$90-120$ & 29.84 & 26.04 \\
$120-150$ & 33.86 & 27.86 \\
\hline
\end{tabular}

Mesocosm sample collection and harvest measures

Four months after the flowering onset, the plants were destructively harvested. Phenotypic traits measured are defined in Table 2. One day before destructive sampling, plant height was recorded using a ruler measured from the mesocosm media surface to the tip of the tallest leaf when held to its maximum height and all tillers were counted. Gas exchange and chlorophyll fluorescence parameters for the youngest fully expanded leaf of each plant were measured using an LI-6800 portable photosynthesis system with Multiphase Flash Fluorometer (LI-COR Biosciences, Lincoln, NE, USA) operating with a six $\mathrm{cm}^{2}$ aperture circular leaf adapter, a flow rate of 600 $\mu \mathrm{mol} \mathrm{mol}{ }^{-1}$, and a cuvette relative humidity of $60 \% . \mathrm{CO}_{2} \mathrm{ex}-$ change was logged manually, with stability criteria for both 20 and 2 standard deviation limits set to 0.1 over a period of 15 s. The leaf maximum width was used to normalize measurements on leaf material smaller than the circular leaf adapter. Then, the mesocosms were injected with ${ }^{15} \mathrm{NO}_{3}$ (98\% atom) to assess deep $\mathrm{N}$ capture by switchgrass roots. Three evenlyspaced passage holes were drilled around the circumference of each mesocosm at $132 \mathrm{~cm}$ depth, and five $\mathrm{mL}$ of $\mathrm{Ca}\left(15 \mathrm{NO}_{3}\right)_{2}$ solution $\left(0.46 \mathrm{mg}^{15} \mathrm{NO}_{3} \mathrm{~mL}^{-1}\right)$ was injected into each mesocosm using these holes with a syringe (Fig. 1B).

The next day at 24 hours after ${ }^{15} \mathrm{~N}$ injection, the shoot of each plant was severed at the stem base and dried at $60^{\circ} \mathrm{C}$ for $3 \mathrm{~d}$ for dry biomass determination. The shoot samples were thoroughly ground by placing the samples into glass vials with three opposing surgical blades and shaking at a frequency of $30 \mathrm{~Hz}$ for 10 minutes using a Qiagen TissueLyser II (Germantown, MD, USA). Shoot tissue percentages of total $\mathrm{N}$ and ${ }^{15} \mathrm{~N}$ were determined using a BioVisION from Elementar including an IsoPrime Vision isotope ratio mass spectrometer connected to an IsoPrime Isotope cube that operates in CNS mode (Elementar, Langenselbold, Germany).

For root harvesting, the polyethylene bag that lined each mesocosm was pulled out and the bag was sliced open longitudinally on a root washing station (Fig. 1C). One-hundred grams of media mixture samples excluding roots were bagged at $30 \mathrm{~cm}$ layers for measuring gravimetric water content and $\mathrm{N}$ content, as detailed above, and were placed in a cool box containing ice and frozen at $-20{ }^{\circ} \mathrm{C}$ within eight hours. The rest of the mixture was then carefully washed away from the roots using a water hose with a low-pressure nozzle starting at the plant base. Immediately after root washing, roots were cut and divided into $30 \mathrm{~cm}$ layers, and root respiration for each plant 
bioRxiv preprint doi: https://doi.org/10.1101/2021.02.19.432036; this version posted February 22, 2021. The copyright holder for this preprint (which was not certified by peer review) is the author/funder, who has granted bioRxiv a license to display the preprint in

Table 2. Traits measured and descriptors used in this study. Calculations for derived traits are found in the Supplementary R code. Traits measured in per plant basis refers to the entire plant within one biological unit.

\begin{tabular}{|c|c|c|c|}
\hline Trait category & Trait description & Method & Units \\
\hline \multirow[t]{16}{*}{ Total root size } & Root dry mass total & Measured after 3 days at $60^{\circ} \mathrm{C}$ & g plant ${ }^{-1}$ \\
\hline & Root $\mathrm{CO} 2$ flux total & LI-8100A & nmol plant ${ }^{-1} \mathrm{~s}^{-1}$ \\
\hline & Root length total & RhizoVision Explorer & mm plant ${ }^{-1}$ \\
\hline & Root length axial & RhizoVision Explorer & mm plant ${ }^{-1}$ \\
\hline & Root length lateral & RhizoVision Explorer & mm plant ${ }^{-1}$ \\
\hline & Root length secondary lateral & RhizoVision Explorer & mm plant ${ }^{-1}$ \\
\hline & Root surface area total & RhizoVision Explorer & mm2 plant ${ }^{-1}$ \\
\hline & Root surface area axial & RhizoVision Explorer & $\mathrm{mm} 2$ plant $^{-1}$ \\
\hline & Root surface area lateral & RhizoVision Explorer & mm2 plant ${ }^{-1}$ \\
\hline & Root surface area secondary lateral & RhizoVision Explorer & $\mathrm{mm} 2$ plant $^{-1}$ \\
\hline & Root volume total & RhizoVision Explorer & mm3 plant ${ }^{-1}$ \\
\hline & Root volume axial & RhizoVision Explorer & mm3 plant ${ }^{-1}$ \\
\hline & Root volume lateral & RhizoVision Explorer & mm3 plant ${ }^{-1}$ \\
\hline & Root volume secondary lateral & RhizoVision Explorer & mm3 plant ${ }^{-1}$ \\
\hline & Root branch count total & RhizoVision Explorer & - \\
\hline & Root tip count total & RhizoVision Explorer & - \\
\hline \multirow[t]{7}{*}{ Root distribution } & Specific root length & Root length / Root dry mass (derived) & $\mathrm{m} \mathrm{g}^{-1}$ \\
\hline & Root lateral:axial ratio & $\begin{array}{l}\text { Lateral + secondary lateral root length / crown } \\
\text { root length (derived) }\end{array}$ & - \\
\hline & Root branching frequency & RhizoVision Explorer & freq $\mathrm{mm}^{-1}$ \\
\hline & $\begin{array}{l}\text { Deep root dry mass total (mass ba- } \\
\text { sis) }\end{array}$ & Root dry mass in $120 \mathrm{~cm}-150 \mathrm{~cm}$ soil horizon & g plant ${ }^{-1}$ \\
\hline & Deep root length total (length basis) & Root length in $120 \mathrm{~cm}-150 \mathrm{~cm}$ soil horizon & mm plant ${ }^{-1}$ \\
\hline & Deep root fraction (mass basis) & $\begin{array}{l}\text { Root dry mass in } 120 \mathrm{~cm}-150 \mathrm{~cm} \text { soil horizon / to- } \\
\text { tal root dry mass (derived) }\end{array}$ & g g1 \\
\hline & Deep root fraction (length basis) & $\begin{array}{l}\text { Root length in } 120 \mathrm{~cm}-150 \mathrm{~cm} \text { soil horizon / total } \\
\text { root length (derived) }\end{array}$ & $\mathrm{mm} \mathrm{mm1}$ \\
\hline \multirow[t]{3}{*}{ Root diameter } & Root maximum diameter & RhizoVision Explorer & mm plant ${ }^{-1}$ \\
\hline & Root median diameter & RhizoVision Explorer & mm plant ${ }^{-1}$ \\
\hline & Root average diameter & RhizoVision Explorer & mm plant ${ }^{-1}$ \\
\hline \multirow[t]{3}{*}{ Root respiration } & Root $\mathrm{CO} 2$ flux total & LI-8100A & nmol plant ${ }^{-1} \mathrm{~s}^{-1}$ \\
\hline & Specific root $\mathrm{CO} 2$ flux (length basis) & LI-8100A and root length (derived) & $\mathrm{nmol} \mathrm{m} \mathrm{m}^{-1} \mathrm{~s}^{-1}$ \\
\hline & Specific root $\mathrm{CO} 2$ flux (mass basis) & LI-8100A and root dry mass (derived) & $\mathrm{nmol} \mathrm{g}^{-1} \mathrm{~s}^{-1}$ \\
\hline \multirow[t]{2}{*}{ Biomass distribution } & Plant dry mass total & Root + Shoot dry mass (derived) & g plant $^{-1}$ \\
\hline & Root mass fraction & Root dry mass / total dry mass (derived) & g g1 \\
\hline \multirow[t]{5}{*}{ Shoot size } & Shoot dry mass total & Measured after 3 days at $60^{\circ} \mathrm{C}$ & g plant ${ }^{-1}$ \\
\hline & Plant height & Manual measurement soil level to leaf tip & $\mathrm{cm}_{\text {plant }}{ }^{-1}$ \\
\hline & Leaf maximum width & Manual measurement widest leaf width & $\mathrm{cm}_{\text {plant }}{ }^{-1}$ \\
\hline & Tiller count & Manual count & - \\
\hline & Total leaf $\mathrm{N}$ & EA IRMS System & g plant $^{-1}$ \\
\hline \multirow[t]{10}{*}{ Shoot properties } & Leaf $\mathrm{N}$ concentration & EA IRMS System & $\%$ \\
\hline & Leaf protein percent & EA IRMS System & $\%$ \\
\hline & Leaf $\mathrm{C}$ concentration & EA IRMS System & $\%$ \\
\hline & Net $\mathrm{CO} 2$ assimilation rate $(\mathrm{A})$ & LI- 6800 & umol m $\mathrm{m}^{-2} \mathrm{~s}^{1}$ \\
\hline & Shoot $15 \mathrm{~N}$ concentration & EA IRMS System & $\%$ \\
\hline & Shoot $15 \mathrm{~N}$ content & EA IRMS System & mg plant $^{-1}$ \\
\hline & Shoot $15 \mathrm{~N}$ uptake rate & EA IRMS System & $\mathrm{mg} \mathrm{h}^{-1}$ plant $^{-1}$ \\
\hline & Leaf transpiration rate $(\mathrm{E})$ & LI- 6800 & $\mathrm{~mol} \mathrm{~m}^{-2} \mathrm{~s}^{1}$ \\
\hline & Leaf stomatal conductance (gsw) & LI- 6800 & $\mathrm{~mol} \mathrm{~m}^{-2} \mathrm{~s}^{1}$ \\
\hline & $\begin{array}{l}\text { Intercellular } \mathrm{CO} 2 \text { partial pressure } \\
\text { (Pci) }\end{array}$ & LI-6800 & - \\
\hline
\end{tabular}

and layer was measured (Fig. 1D and E). All roots from each ${ }_{230}$ layer were transferred into a custom $43 \mathrm{~mL}$ airtight chamber ${ }_{231}$ (as detailed in (Guo et al., 2020)) connected to an LI-8100 Automated Soil CO2 Flux System (LI-COR Biosciences, NE, USA). ${ }^{232}$ A representative subsample of roots was measured if there was ${ }^{233}$ too much root materials to fit into the chamber. The $\mathrm{CO} 2$ flux $^{234}$ in the chamber was measured with an observation duration of ${ }^{235}$ 90 seconds using the LI-8100A v4.0.9 software (Fig. 1D). Total ${ }^{236}$ respiration rate was calculated automatically by the linear fit ${ }^{237}$ mode in SoilFluxPro v4.0.1 software (LI-COR Biosciences, $\mathrm{NE}^{238}$ USA) with a curve-fit time of $20-90$ seconds. After the root ${ }^{239}$ respiration measurement, the root material was bagged indi- $-^{240}$ vidually by plant, media layer, and by subsample if required ${ }^{24}$
(Fig. 1E). The root material was then placed in a cool box containing ice and frozen at $-20{ }^{\circ} \mathrm{C}$ within eight hours.

The bagged root samples were later thawed and imaged using a flatbed scanner equipped with a transparency unit (Epson Expression 12000XL, Epson America Inc, Los Alamitos, CA, USA). Roots were spread out on a transparent acrylic tray ( 420 $\mathrm{mm} \times 300 \mathrm{~mm})$ with a five $\mathrm{mm}$ layer $(400 \mathrm{~mL})$ of water and imaged at a resolution of 600 dpi as JPG files with $95 \%$ (high) quality. Multiple root scans were done when too much root material was present to scan in a single image to minimize root overlapping based on subjective determination, with an average root length of $10 \mathrm{~m}$ per scan retroactively calculated, and the cumulative root length was computed in R. The axial, 
bioRxiv preprint doi: https://doi.org/10.1101/2021.02.19.432036; this version posted February 22, 2021. The copyright holder for this preprint (which was not certified by peer review) is the author/funder, who has granted bioRxiv a license to display the preprint in

first-order lateral and second-order lateral root lengths, sur-29 face area, and volume for each plant was calculated from the flatbed images using RhizoVision Explorer v2.0.2 (Seethepalli ${ }_{29}$ and York, 2020) based on diameter thresholds (in $\mathrm{mm}$ ) of $>0.9$, $0.3-0.9$, and $<0.3$, respectively. The threshold level was set to ${ }_{300}$ 200 , filter non-root objects set to $10 \mathrm{~mm}^{2}$, and root pruning ${ }_{30}$ threshold set to 20 pixels. Total root tip number, branching fre- ${ }_{302}$ quencies, and average root diameter were also calculated in the ${ }_{303}$ software. During statistical analysis, the ratio of lateral roots ${ }_{304}$ (first- and second-order) to the axial traits was computed as ${ }_{305}$ lateral-to-axial ratios. After scanning, the root material was ${ }_{306}$ placed in a paper envelope and dried at $60{ }^{\circ} \mathrm{C}$ for three days ${ }_{30}$ for determination of root dry weight. Root mass fraction was ${ }_{308}$ calculated by dividing the total root dry mass by the total plant ${ }_{309}$ dry mass, and deep root fraction as the root length or mass ${ }_{310}$ in the bottom 120-150 cm layer divided by the respective total ${ }_{311}$ root system length or mass.

\section{Statistical analysis}

Statistical analyses were conducted using $\mathrm{R}$ version ${ }_{319}$ 4.0.3 ( $\mathrm{R}$ Core Team, 2020); the statistical analysis $\mathrm{R}_{320}$ codes including the packages needed are available at ${ }_{32}$ https://doi.org/10.5281/zenodo.4281435 (Griffiths et al., 2021). Traits calculated are described in Table 2. Analysis of variance ${ }_{323}$ (ANOVA) of the plant data was conducted using the R package ${ }_{324}$ "ImerTest" (Kuznetsova et al., 2017) with block as the random ${ }_{325}$ effect. The Tukey's HSD test used for the multiple comparison ${ }_{326}$ boxplots was conducted using the $\mathrm{R}$ package "agricolae" ${ }_{327}$ (De Mendiburu and Simon, 2015). The correlation matrix ${ }_{328}$ was generated using the $\mathrm{R}$ package "corrplot" (Wei and ${ }_{329}$ Simko, 2017) with plant trait data for both genotypes across all conditions. Linear discriminant analysis was conducted using the 'lda' function from the MASS package (Venables ${ }_{332}$ and Ripley, 2002) to predict genotype, water treatment, or nitrogen treatment classes in separate analyses. Before LDA, ${ }_{334}$ data were standardized for each trait so that the mean was ${ }_{335}$ zero and the within-group standard deviation was 1 in order to interpret loadings.

\section{Results}

Positive correlations among root size traits and deep ${ }_{34}$ rooting traits with shoot size traits in switchgrass

Across both switchgrass ecotypes and all conditions, a cor-34 relation matrix showed strong positive correlations among ${ }_{349}$ root size-related traits, deep rooting traits, shoot size-related 350 traits, and ${ }^{15} \mathrm{~N}$ content of leaves $\left(\mathrm{P}<0.05\right.$, Fig. 2). Root length, ${ }^{35}$ surface area, and volume traits were highly correlated $(\mathrm{P}<0.05$, Fig. S1). For the specific root traits, positive correlations were observed between specific root length, specific root respiration (length and mass basis), and ${ }^{15} \mathrm{~N}$ percent of leaves $(\mathrm{P}<0.05$, Fig. 2). For deep root fraction, the only correlated traits, aside from deep root mass, were for secondary lateral root traits and ${ }^{354}$ plant height $\left(\mathrm{P}<0.05\right.$, Fig. 2). Gas exchange (Assimilation rate, ${ }^{355}$ transpiration rate, and stomatal conductance) and chlorophyll ${ }^{350}$ fluorescence parameters for the new fully expanded leaf were ${ }^{357}$ uncorrelated with all other measured plant traits (Fig. 2).
Substantial phenotypic variation between the upland and lowland ecotypes for root and shoot traits representing the wide genetic pool of switchgrass

For the plant traits measured, substantial differences between the upland and lowland ecotypes were observed. Common to all conditions tested, total genotype-associated differences between the ecotypes were observed for total root mass, root class distribution traits including root mass fraction, specific root length, lateral:axial root ratio, and also specific root respiration rate (mass basis), plus leaf maximum width $(\mathrm{P}<0.05$, Fig. 3, Table S2). Across all conditions tested, the lowland ecotype had an average $80 \%$ larger root mass, $32 \%$ higher root mass fraction, $34 \%$ decrease in specific root length, $39 \%$ decrease in lateral:axial root ratio, and a $74 \%$ decrease in specific root respiration rate (mass basis) compared to the upland ecotype (Fig. 3, Table S2). In favorable conditions only, HN/WW, genotypic differences were also observed for tiller count with a $57 \%$ increase in the lowland $(\mathrm{P}<0.05$, Table $\mathrm{S} 3$ and $\mathrm{S} 5)$. In all stress conditions tested (HN/DS, LN/WW, and LN/DS), genotypic differences were observed for root mass in the deepest mesocosm layer with a $50 \%$ larger root mass in the lowland relative to upland under high- $\mathrm{N}$ conditions and a $140 \%$ larger root mass in the upland compared to lowland under drought $(\mathrm{P}<0.05$, Table S4-S6). Under the most severe stress condition, LN/DS, genotypic differences were observed for axial root size traits with a 152\% larger axial root system in the upland (length, surface area, volume $)(\mathrm{P}<0.001$, Table S4 and S6). Additional significant genotypic differences were observed in the LN/WW conditions for plant height, root branching frequency, root tip count, root length proportion in the deepest mesocosm layer compared to all layers, and total $15 \mathrm{~N}$ content captured from the deepest layer with the upland being larger for all $(\mathrm{P}<0.05$, Table S6).

A linear discriminant analysis using the plant traits was performed to determine the differentiating capacity of the plant traits between the two ecotypes. Across all conditions, rooting traits were the greatest discriminant trait between the ecotypes with axial and total root surface area being the greatest discriminators followed by root volume and length traits (Fig. 4A). In favorable conditions, $\mathrm{HN} / \mathrm{WW}$, the main discriminant traits were maximum tiller count, specific root length, leaf maximum width, specific root respiration rate (mass basis), and root mass fraction (Fig. 4B). Common to the well-watered conditions (HN/WW and LN/WW) was specific root respiration as a discriminant factor between the ecotypes (Fig. 4B and D). Common to the low-N conditions (LN/WW and LN/DS) was root maximum diameter as a discriminant factor (Fig. $4 \mathrm{D}$ and $\mathrm{E}$ ). Specific to HN/DS, the main discriminant factors between the switchgrass ecotypes were for shoot $\mathrm{N}$ and $15 \mathrm{~N}$ concentration, and plant height (Fig. 4C). Shoot $15 \mathrm{~N}$ concentration was also a main discriminant for LN/WW. Specific to LN/WW, specific root respiration rate (both mass and length basis) and shoot carbon concentration were the main discriminant traits (Fig. 4D). Specific to LN/DS, root mass at depth and dry mass total were main the discriminant traits (Fig. $4 \mathrm{E}$ ).

\section{Switchgrass ecotypes share common plastic abiotic re- sponses to $\mathrm{N}$ and water availability}

Genotypic differences in phenotypic traits were observed between the upland and lowland ecotypes, however, in terms of abiotic stress responses, common plastic responses were also observed between the ecotypes.

A significant water treatment response was common to both switchgrass ecotypes (HN conditions) with larger axial root traits (length, surface area, volume), lateral root traits (surface 
bioRxiv preprint doi: https://doi.org/10.1101/2021.02.19.432036; this version posted February 22, 2021. The copyright holder for this preprint (which was not certified by peer review) is the author/funder, who has granted bioRxiv a license to display the preprint in 6 | bioRxiv, 2021 perpetuity. It is made available under aCC-BY 4.0 International license.

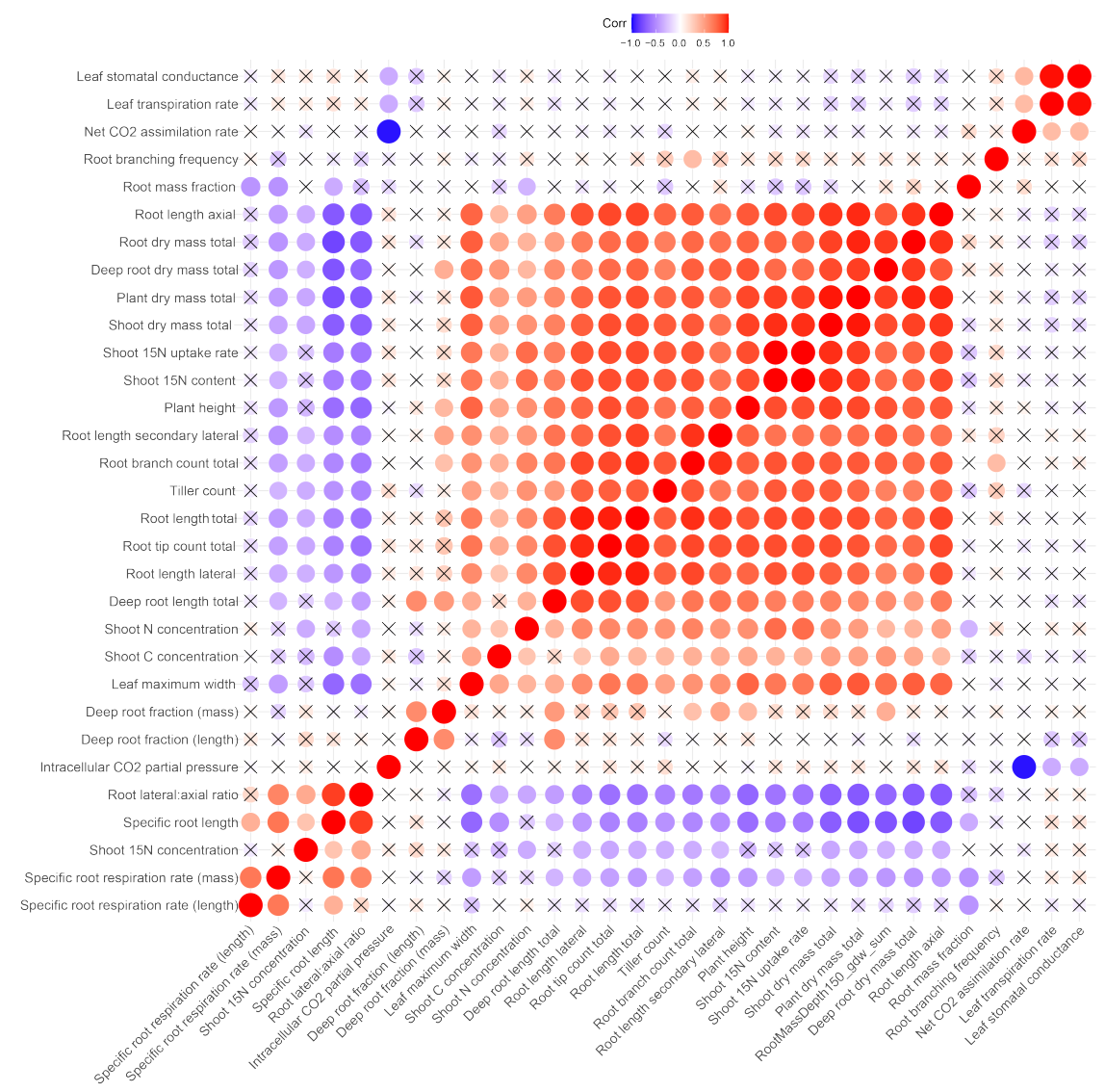

Figure 2. Correlation matrix for plant traits across both switchgrass ecotypes, upland (VS16) and lowland (AP13), and all conditions. Correlations are visualized using a color gradient. Red and blue color represent a strong positive and negative correlation respectively. No correlation is visualized with a cross symbol.
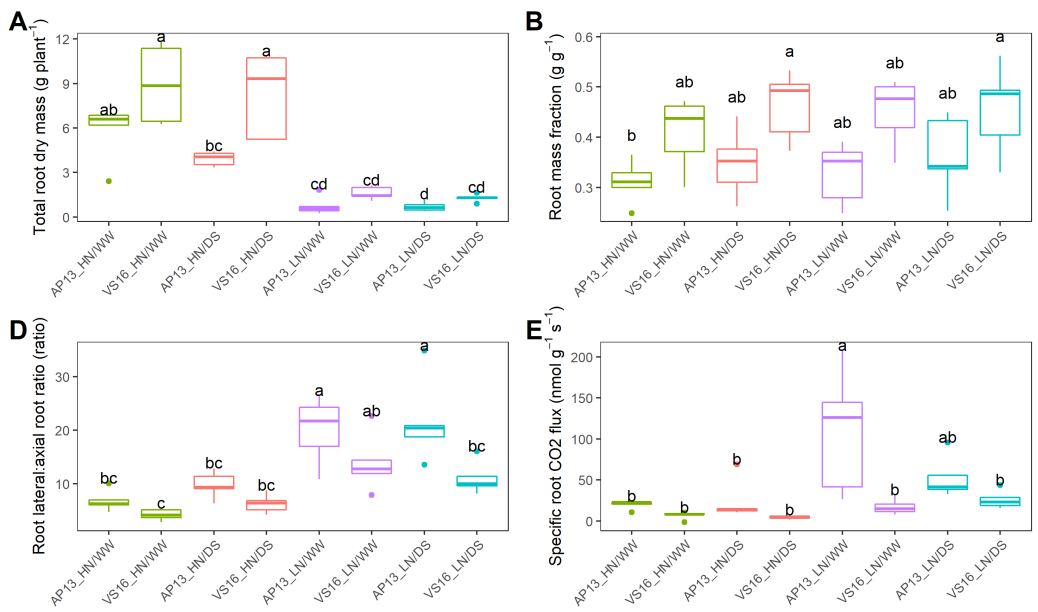

$E_{0}^{\top}$

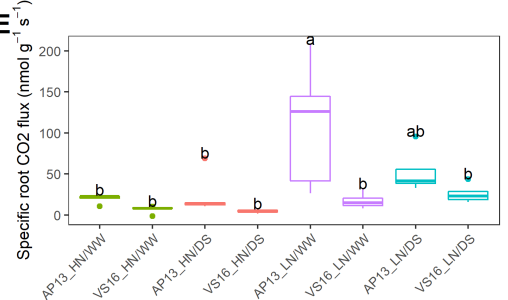

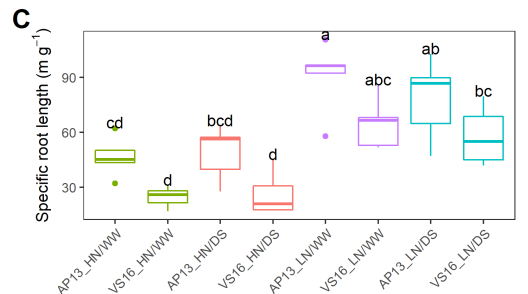

$\mathbf{F}$

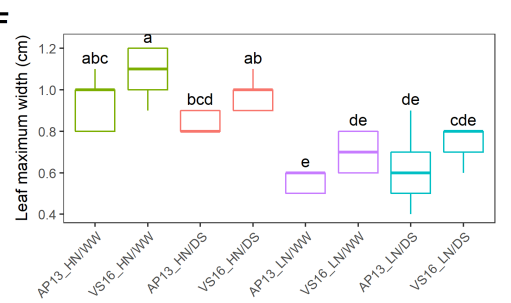

Treatment 官 HN/DS LNIDS LNWW

Figure 3. Total plant traits measured in each abiotic stress environment tested between the two switchgrass ecotypes, upland (VS16) and lowland (AP13). Boxes with the same letter were not significantly different at $\mathrm{P}<0.05$ according to Tukey's HSD test. 
bioRxiv preprint doi: https://doi.org/10.1101/2021.02.19.432036; this version posted February 22, 2021. The copyright holder for this

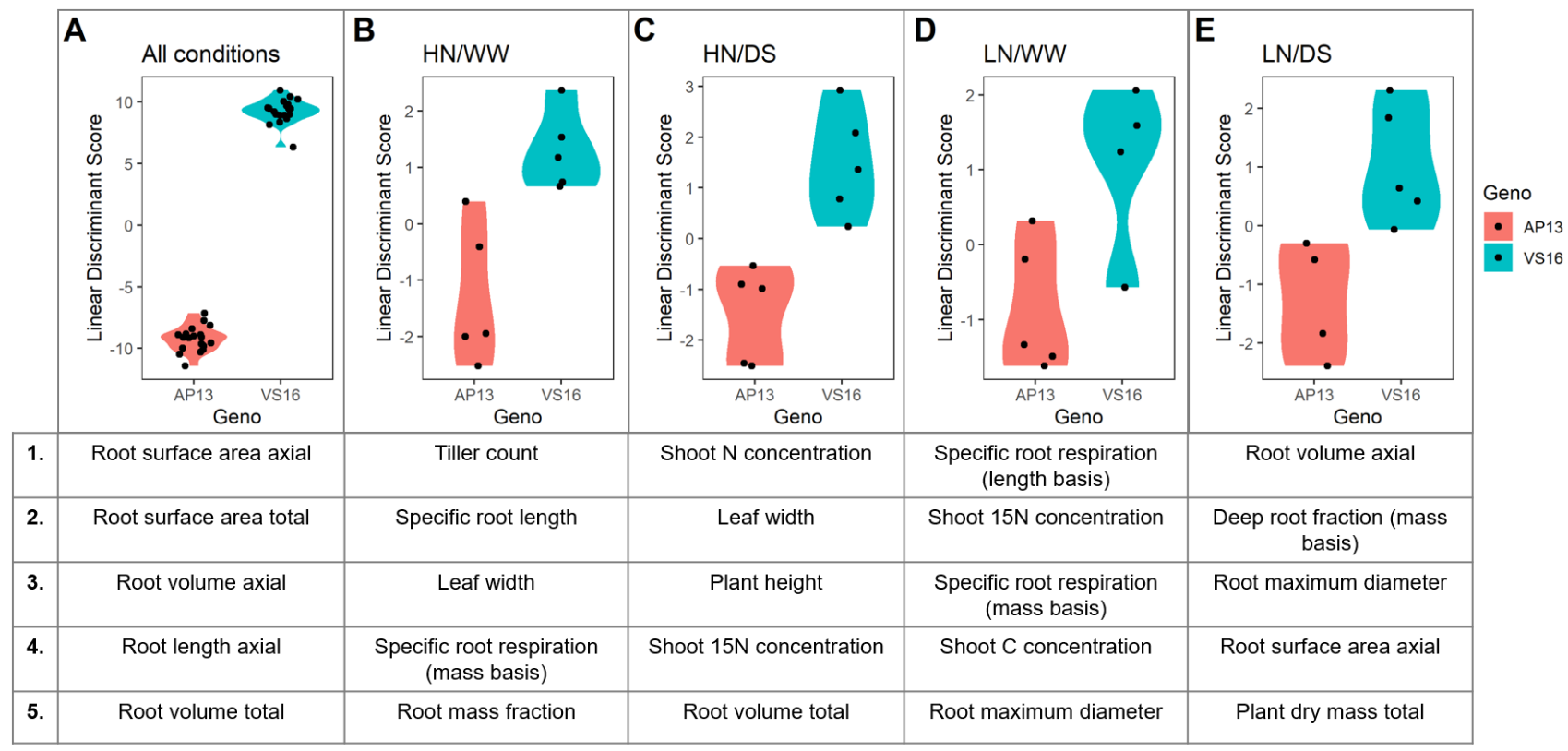

Figure 4. Linear discriminant analysis of total plant traits measured in each abiotic stress environment tested between the two switchgrass ecotypes, upland (VS16) and lowland (AP13). The five greatest discriminant traits by linear discriminant score both positive and negative are listed for each environment. (A) All conditions, (B) HN/WW, (C) HN/DS, (D) LN/WW, (E) LN/DS.

area, volume), root tip count, root maximum diameter, and ${ }_{39}$ shoot traits (tiller count, max leaf width) in well-watered con- ${ }_{39}$ ditions relative to drought-stressed conditions $(\mathrm{P}<0.05$, Table S5). A significant increase in lateral:axial root ratio and deep root fraction (mass basis) was observed in the water-stress conditions (HN conditions) $(\mathrm{P}<0.01$, Table S5). However, these water treatment effects were not observed in the LN conditions ${ }_{403}$ as the $\mathrm{N}$ stress appeared to have had a more severe and con- ${ }_{404}$ founding effect on plant trait differences (Table S6).

In response to $\mathrm{N}$ treatment, a significant treatment effect ${ }^{406}$ was observed for all plant size traits with larger roots and ${ }^{407}$ shoots in high $\mathrm{N}$ conditions (WW and DS conditions, Table $\mathrm{S} 3^{408}$ and $\mathrm{S}_{4}$ ). In low $\mathrm{N}$ conditions, there was a significantly greater ${ }^{40}$ specific root length, lateral:axial root ratio, specific root respiration rate, and deep root fraction relative to the high $\mathrm{N}$ conditions. Traits with no significant difference by $\mathrm{N}$ treatment were for photosynthetic and transpiration measures (Table S3 and S4). No significant difference in root mass fraction was observed for either $\mathrm{N}$ treatments or water treatments with a shared reduction in both root and shoot mass by abiotic stress (Table S3 and S4). Under well-watered conditions, a significant genotype by $\mathrm{N}$ treatment interaction was observed for secondary lateral root size traits, branching frequency, and specific root respiration rate (mass basis) $(\mathrm{P}<0.05$, Table S3). Under drought conditions, a significant genotype by $\mathrm{N}$ treatment interaction was observed for root dry mass total, axial root size traits, deep root mass total, and deep root fraction $(\mathrm{P}<0.05$, Table S4).

A linear discriminant analysis using the plant traits was performed to determine the main discriminant trait between the water levels or $\mathrm{N}$ levels. The discriminant traits between $\mathrm{N}$ and $\mathrm{W}$ treatment levels were found to be rooting traits (Fig. 5A and B). For the $\mathrm{N}$ treatment, lateral and secondary lateral root traits were the top discriminant traits in addition to axial root surface area (Fig. 5A). For the $\mathrm{W}$ treatment, total root surface area and root surface area of each root class were the main discriminants plus axial root length (Fig. 5B).
Roots of both switchgrass ecotypes have the potential to grow deeper than $1.5 \mathrm{~m}$ with significant interaction between root depth related traits and abiotic stress

Across both ecotypes, almost all rooting traits tested were significantly affected by depth (Table S7-S10). Exceptions were for specific root respiration with no significant relationship with mesocosm depth and for lateral:axial root ratio in LN conditions.

Significant interaction between genotype and depth were observed for specific root respiration rate (weight basis) in favorable conditions, HN/WW. In the abiotic stress conditions, a significant genotype and depth interaction was observed for

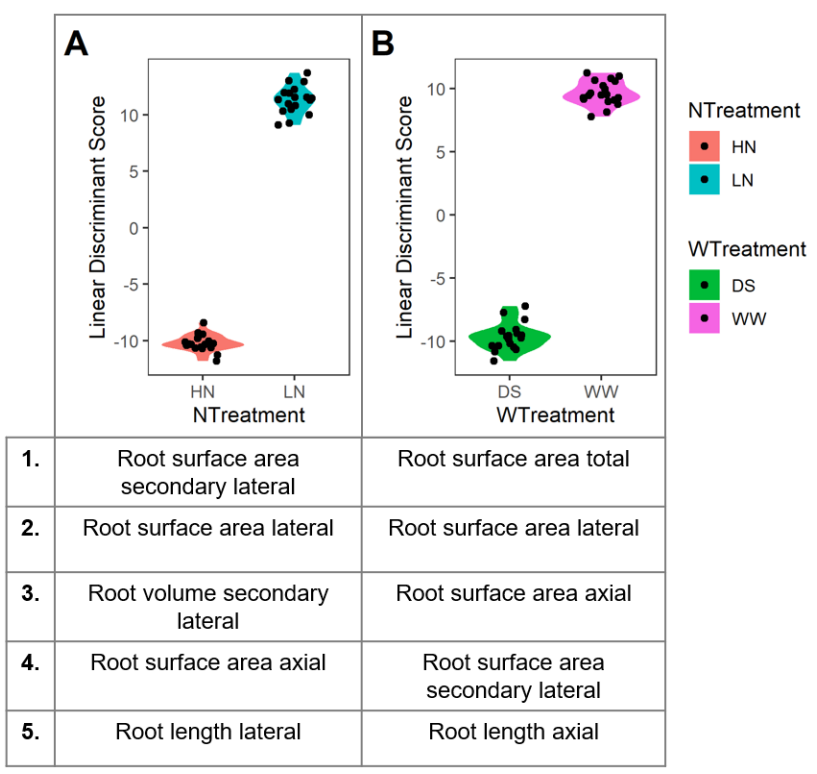

Figure 5. Linear discriminant analysis of total plant traits for both ecotypes to determine common discriminant traits by (A) $\mathrm{N}$ treatments, and (B) water treatments. The five greatest discriminant traits by linear discriminant score both positive and negative are listed from all environment data. 
bioRxiv preprint doi: https://doi.org/10.1101/2021.02.19.432036; this version posted February 22, 2021. The copyright holder for this preprint (which was not certified by peer review) is the author/funder, who has granted bioRxiv a license to display the preprint in 8 bioRxiv, 2021 perpetuity. It is made available under aCC-BY 4.0 International license.

lateral root traits (length and surface area) in LN/WW, root ax-472 ial traits (length and surface area) and root average diameter ${ }_{473}$ in LN/DS, and root maximum diameter in HN/DS.

The root distribution across the vertical profile varied 475 greatly by water and nitrogen conditions (Fig. 6A). For both 476 switchgrass ecotypes, total root length was greatest in the fa-477 vorable condition, HN/WW, and least in the combined stress 478 condition, LN/DS. In favorable conditions, there was no signif-479 icant genotypic difference in root length by layer. However, in 480 the low- $\mathrm{N}$ conditions, the upland ecotype had a greater root 481 length in the deepest layer compared to the lowland ecotype. 482 The greatest difference between the ecotypes was observed in ${ }^{483}$ the LN/WW condition with the upland ecotype having a 193\%484 increased root length in the deepest layer, with the LN/DS con-485 dition reducing further the root length at depth for both eco-480 types. The differences observed in the root length by depth ${ }_{487}$ also conferred with the shoot $15 \mathrm{~N}$ content results with a $500 \% 488$ average greater $15 \mathrm{~N}$ uptake in the $\mathrm{HN}$ condition plants than in 489 the LN conditions, reflecting uptake 24 hours after $15 \mathrm{~N}$ was in -490 jected to the bottom layer (Fig. 6B and C). An increase in lateral 491 and secondary lateral roots in the upland ecotype contributed 492 to this root length increase in the deepest mesocosm layer (Fig. ${ }_{493}$ 6A). A positive significant relationship was observed between 494 the root length in the deepest layer and $15 \mathrm{~N}$ content in shoot 495 material with greater root length conforming to greater $15 \mathrm{~N} 496$ uptake $(\mathrm{P}<0.001$, Fig. $6 \mathrm{D})$.

\section{Significant interaction between $\mathrm{N}$ and W stress combi ${ }^{490}$} nation treatments for axial and lateral root traits

Using the whole dataset containing both ecotypes and all conditions, interactions between $\mathrm{N}$ and water treatment were $\mathrm{ex}_{-504}$ plored. Across all conditions, significant interactions between ${ }_{505}$ $\mathrm{N}$ and water treatment were observed for axial root traits $\mathrm{s}_{506}$ (length, surface area, volume), total root traits (volume, sur- ${ }_{507}$ face area), deep root fraction (mass basis) compared to all ${ }_{508}$ ${ }_{44}$ depths, shoot ${ }^{15} \mathrm{~N}$ content, ${ }^{15} \mathrm{~N}$ uptake rate, and shoot mass ${ }_{509}$ ${ }_{445}\left(\mathrm{P}<0.05\right.$, Table S11). In the lowland ecotype only, an inter- $-_{510}$ ${ }_{44}$ action between $\mathrm{N}$ and water treatment was also observed for ${ }_{511}$ ${ }_{447}$ tiller count, total plant dry mass, and shoot N\% ( $<<0.05$, Ta- ${ }_{512}$ ${ }_{448}$ ble S12). In the upland ecotype only, an interaction between ${ }_{513}$ ${ }_{449} \mathrm{~N}$ and water treatment was observed for secondary lateral root ${ }_{514}$ 450 traits (length and surface area) $(\mathrm{P}<0.05$, Table S13).

\section{Discussion}

Here, we show that members of two main ecotypes of switchgrass, upland (VS16) and lowland (AP13), share common root ${ }_{521}$ plastic response strategies to abiotic stress despite having large $\mathrm{e}_{522}$ intrinsic root morphological differences. Appropriate growth ${ }_{523}$ responses to abiotic stress can be important stress mitigation ${ }_{524}$ strategies with efficient soil exploration for required resources..$_{525}$ Despite previous studies finding switchgrass productivity of ${ }_{526}$ cultivar 'Cave-in-Rock' to be not receptive to fertilizer treatments (Duran et al., 2016), here a large N treatment effect was ${ }_{528}$ found in both switchgrass ecotypes. Potentially, this cultivar could have a different $\mathrm{N}$ response, the field experiment could ${ }_{530}$ have been growth-limited by other factors, or else the field soil ${ }_{531}$ had more residual available $\mathrm{N}$ than in the $\mathrm{LN}$ mesocosms. In $_{532}$ response to $\mathrm{N}$ application in the current experiment, all plant ${ }_{533}$ size traits were significantly affected with an overall reduction ${ }_{534}$ in root and shoot size traits under stress conditions. Similarly, ${ }_{535}$ water-stress conditions in this study had significant plant size ${ }_{536}$ reducing effects for both root and shoot traits.

The switchgrass root system makes up a large proportion ${ }_{538}$ of the plant biomass with $34 \%$ of total biomass as roots for ${ }_{539}$ the lowland ecotype and $44 \%$ of total biomass in the upland ecotype in these single year plants, averaged across all treatments. Switchgrass can sequester a large amount of carbon and has been shown to increase soil carbon levels over time (Ma et al., 2001). Interestingly, the differences observed in root mass fraction in this study was by ecotype only with a stable fraction across water and $\mathrm{N}$ conditions. A significant interaction between drought and $\mathrm{N}$ stress conditions was observed in switchgrass for axial and lateral root traits representing a complex and shared root development strategy for stress mitigation. Both ecotypes had a smaller axial and lateral root length in the stressed conditions compared to the favorable conditions, probably driven by a reduction in growth and photosynthate availability. A similar relationship was found across 12 temperate herbaceous species with changes in belowground biomass allocation in response to nutrient supply but no change in root mass fraction (Freschet et al., 2015). For switchgrass, the main discriminants between favorable and stress conditions, water and N, across both ecotypes were for total root surface area size traits. Roots are a large carbon investment and maintenance cost to the plant and therefore a reduced root axial investment under stressed conditions is an efficient plastic root response. These innate responses to abiotic stress reflect the hardiness of the species and the ideal nature of switchgrass as a low-input crop (Vogel, 1996).

Specifically, in response to $\mathrm{N}$ conditions, lateral root traits were also found to be the main discriminants. Lateral roots are regarded as the primary site for the uptake of soil resources and often the greatest contributor to total root length and surface area in contact with soil (Hund et al., 2009; Yu et al., 2019). Total root length was reduced under $\mathrm{N}$ stress indicating that the plant was unable to sustain the total carbon cost of a large root system However, the inability to maintain the larger total size was partially compensated by more efficient carbon use by increasing the allocation to cheaper lateral roots, as shown by the greater lateral:axial root ratio. An increase in resource distribution to lateral roots, therefore, increased the root exploration in the soil with a reduced resource allocation to roots which can be seen as an efficient abiotic stress adaptive response, as also shown in maize (Guo and York, 2019). This highlights the importance of lateral roots for abiotic stress mitigation in switchgrass and that selection for improved, resource-efficient switchgrass varieties could use lateral:axial root ratio as a selection criterion for further investigation. This trait is convenient as it can be measured in a subsample of the root system, rather than requiring full excavation or measurements of entire root systems.

Switchgrass can be found across a wide range of climatic conditions and the upland and lowland ecotype represent the main divergent groups. Members of each ecotype, AP13 and VS16, were chosen for this study as AP13 is the source of the lowland reference genome and mapping populations have been derived from the two ecotypes (Milano et al., 2016). Variation among these ecotypes and others could be harnessed for improving abiotic stress tolerance and yield. Between these two switchgrass ecotypes, large morphological differences were observed in root traits with potential implications for abiotic stress tolerance. In a previous study, the upland ecotype was found to be more drought tolerant and had higher nitrogen demand than the lowland ecotype in 1-gallon pot trials, but the root traits were not quantified (Milano et al., 2016). In this single year study, a greater root mass was found in the upland ecotype in all conditions, which may be a contributor to its greater drought tolerance potential, although a shoot biomass difference was not observed. Across all conditions, rooting traits were the greatest discriminant between the ecotypes with lateral and secondary lateral roots being the main discriminants by $\mathrm{N}$ condition. The two ecotypes did not differ by shoot 
bioRxiv preprint doi: https://doi.org/10.1101/2021.02.19.432036; this version posted February 22, 2021. The copyright holder for this preprint (which was not certified by peer review) is the author/funder, who has granted bioRxiv a license to display the preprint in perpetuity. It is made available under aCC-BY 4.0 International license.

A
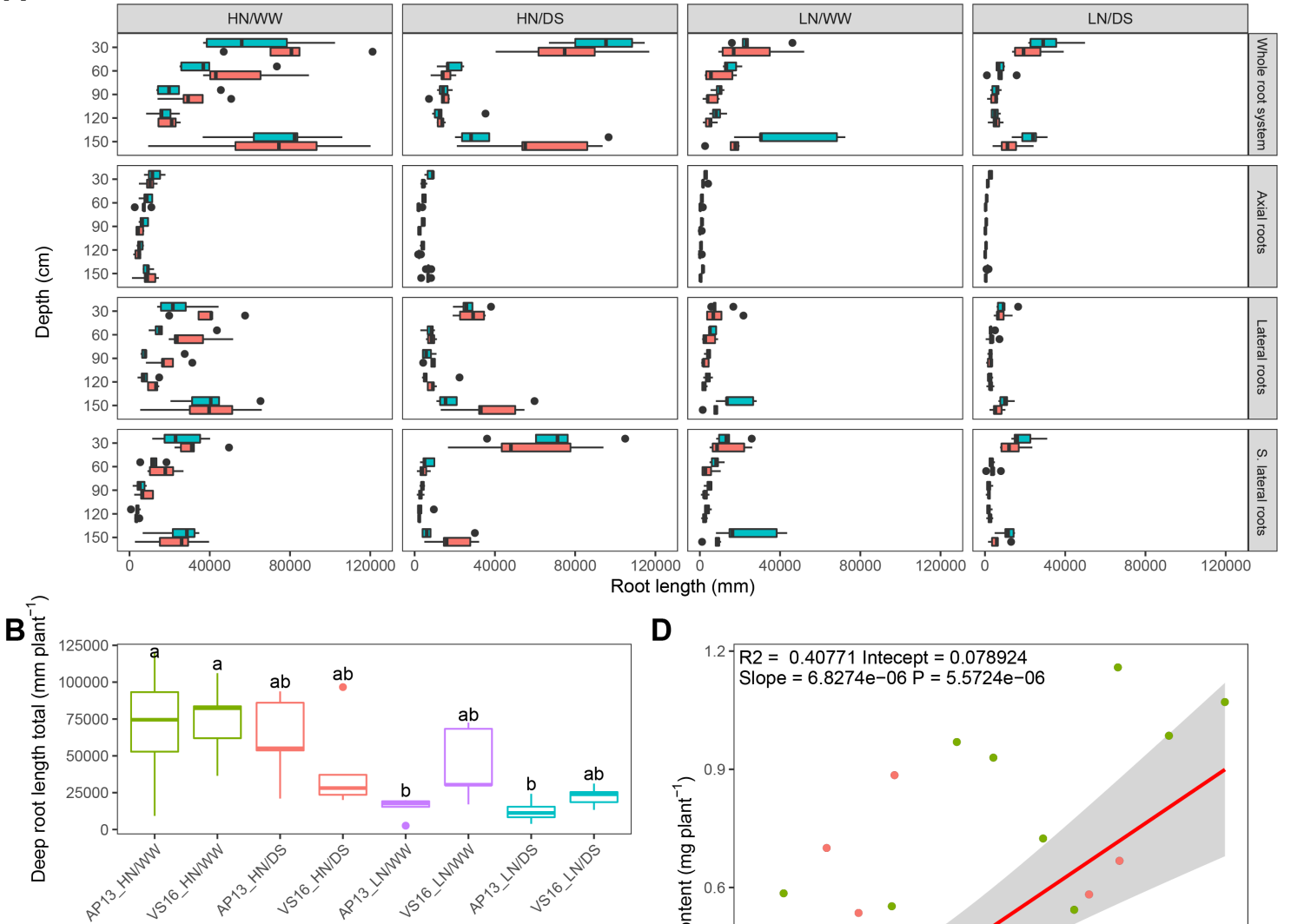

D
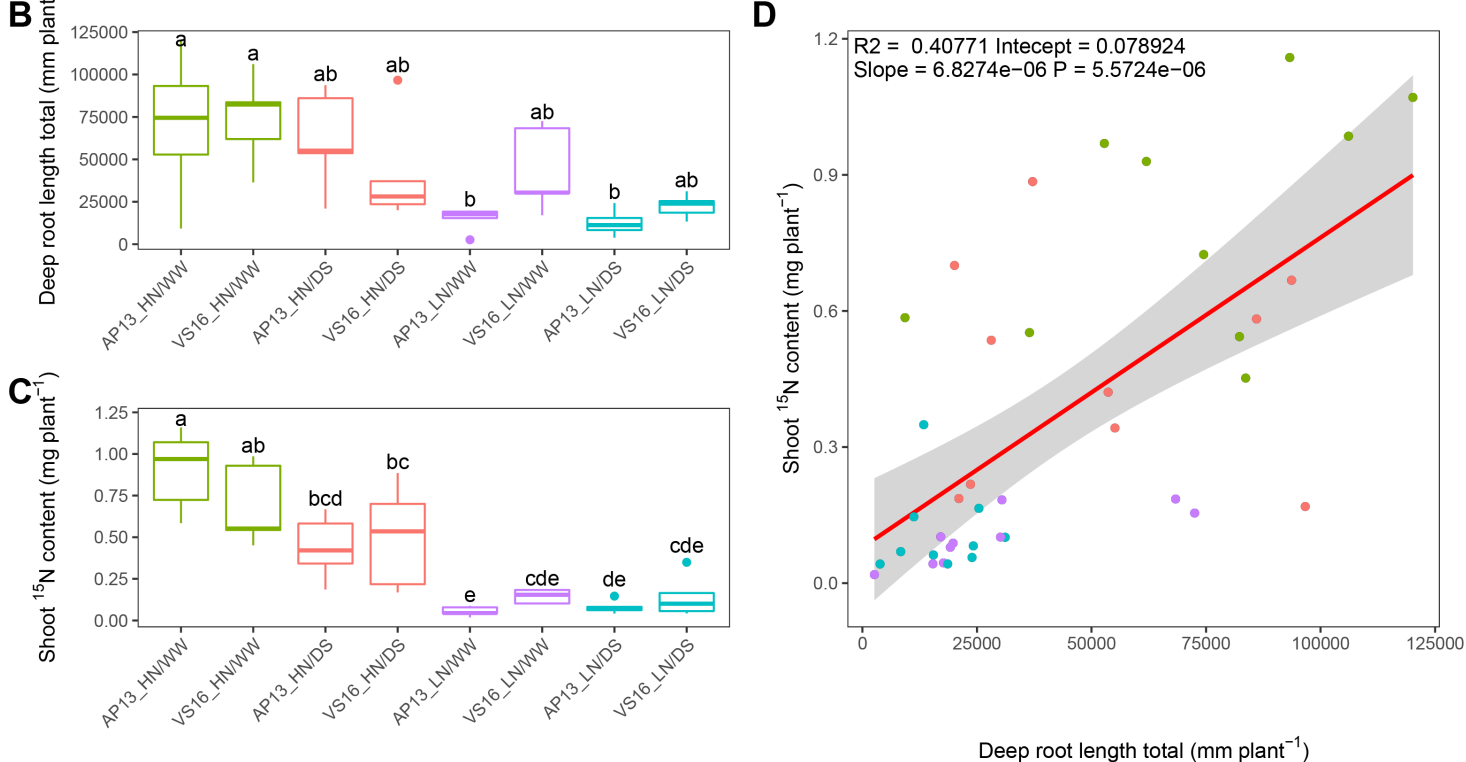

AP13

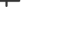

Treatment

宁 HN/DS

官 HN/WW

官 LN/DS

官 LNWW

Deep root length total ( $\mathrm{mm}$ plant ${ }^{-1}$ )

Figure 6. Root distribution of upland (VS16) and lowland (AP13) switchgrass ecotypes across $1.5 \mathrm{~m}$ mesocosms under abiotic stress environment. The roots distributions by root class were separated into $30 \mathrm{~cm}$ mesocosm layers. (B) Root length in the deepest layer and (C) $15 \mathrm{~N}$ content in the shoot for the switchgrass ecotypes by treatment condition. Boxes with different letters were significantly different at $\mathrm{P}<0.05$ according to Tukey's HSD test. (D) Linear regression analysis using all data between root length in the deepest layer and $15 \mathrm{~N}$ content in the shoot. 
bioRxiv preprint doi: https://doi.org/10.1101/2021.02.19.432036; this version posted February 22, 2021. The copyright holder for this preprint (which was not certified by peer review) is the author/funder, who has granted bioRxiv a license to display the preprint in 10 bioRxiv, $2021 \quad$ perpetuity. It is made available under aCC-BY 4.0 International license.

mass per condition in this study, but there was a significant tiller count difference with the lowland having a greater number of tillers in favorable conditions (HN/WW). Tiller counts 608 in switchgrass have been shown to vary greatly year by yearoos in field trials which is a likely response to the environment 610 including rainfall patterns and competition with neighboring ${ }^{61}$ plants (Cassida et al., 2005; Price and Casler, 2014). The upland ecotype maintained the same number of tillers between the nitrogen and water conditions indicating stability across abiotic stress. The lowland ecotype tillered more in favorable conditions which may translate to an increase in overall shoot ${ }^{61}$ biomass and resilience across multiple years. Therefore, the ${ }^{614}$ upland and lowland ecotypes have varying strategies and adap- ${ }^{6}$ tations that may translate to stress resistance and productivity in varying environments. Upland alleles have been previously ${ }_{6}$ associated with shoot size and vigor which may explain the greater root mass differences observed between the ecotypes ${ }_{617}$ in this study (Lowry et al., 2019).

An important plant trait for water and nutrient capture is ${ }^{619}$ deep rooting, however, it is technically challenging to excavate a representative root system from the field and quantify root length by soil depths. In this study, $1.5 \mathrm{~m}$ mesocosms were used to phenotype root distribution in switchgrass in $30 \mathrm{~cm}$ layers along the vertical profile with minimal root loss com-622 pared to field studies. Switchgrass is a particularly deep-rooted ${ }_{623}$ species, and in this study, a positive correlation was found be- ${ }_{-24}$ tween root length at depth and deep $15 \mathrm{~N}$ capture by roots. Both ${ }_{625}$ ecotypes had roots in the deepest layer and had the potential to grow deeper than $1.5 \mathrm{~m}$, given the substantial root length density in the bottom layers. Deep rooting is an important ${ }_{62}$ trait for crop performance because water and nitrate are often found in deep soil layers. Variance observed in switchgrass ${ }^{627}$ root size traits and $15 \mathrm{~N}$ capture were found to explain differ ${ }^{-628}$ ences in shoot mass highlighting the link between root and ${ }^{629}$ shoot. Between the upland and lowland ecotypes, differences ${ }^{630}$ in abiotic stress mitigation strategies were observed. Across ${ }^{631}$ all stress conditions tested, a genotype-associated difference was observed between the upland and lowland ecotypes for root mass in the deepest layer of the mesocosm. In the low- $\mathrm{N}$ con-63 ditions, a greater root length and mass were observed in the upland ecotype which conformed to a greater $15 \mathrm{~N}$ shoot content ${ }^{633}$ which was applied to the deepest layer. Therefore, the upland ${ }^{634}$ ecotype was more receptive to the vertical $\mathrm{N}$ stress gradient ${ }^{635}$ with greater root development at depth and greater $\mathrm{N}$ uptake, ${ }^{636}$ which is an advantageous trait for low input cropping systems. ${ }^{637}$ Given the difficulties in excavating root systems and soil cor- ${ }^{638}$ ing in the field, injection of ${ }^{15} \mathrm{~N}$ in deep layers and measuring ${ }^{639}$ uptake in the shoot is a viable method to screen for deep root $-{ }^{640}$ ing activity. Interestingly, in response to drought conditions, ${ }^{641}$ the lowland ecotype had a smaller root mass compared to the ${ }^{642}$ upland ecotype in the deepest layer, however, the upland had $a^{643}$ greater proportion of roots in this bottom layer. This indicates ${ }^{644}$ a root length distribution change to the vertical gradient wa- ${ }^{645}$ ter stress in the lowland ecotype and could be an advantageous ${ }^{646}$ drought tolerance trait.

Our findings highlight the importance of the root system with switchgrass ecotypes sharing common strategies for abi- - $50_{50}$ otic stress mitigation and deep $\mathrm{N}$ capture. We also show that ${ }_{651}$ the ecotypes have differing strategies to abiotic stress toler-652 ance with biomass distribution changes and deep rooting in ${ }_{653}$ response to factorial water and $\mathrm{N}$ stress. Admixture between ${ }_{654}$ the divergent genomes is expected to enhance climate adapta- 655 tion and yield improvement (Lovell et al., 2021). For switch-556 grass to be a productive bioenergy crop a balance between pro-657 ductivity and resource sustainability will have to be reached by ${ }_{658}$ enhancing plant abiotic stress tolerance and soil resource use 659 efficiency.

\section{Availability of supporting data and materials}

The dataset supporting the results of this article is available online as a Zenodo repository https://doi.org/10.5281/zenodo.4281435 (Griffiths et al., 2021).

\section{Competing Interests}

The authors declare that the research was conducted in the absence of any commercial or financial relationships that could be construed as a potential conflict of interest.

\section{Funding}

Funding provided by The Center for Bioenergy Innovation a U.S. Department of Energy Research Center supported by the Office of Biological and Environmental Research in the DOE Office of Science.

\section{Author's Contributions}

L.M.Y. and M.G. conceived the research. M.G., H.G., K.D., and A.S. contributed to the experimentation. M.G., A.S., and L.M.Y. analyzed the data. All authors contributed to the writing of the manuscript.

\section{Acknowledgements}

The authors would like to thank Michael Cloyde, Yaxin Ge, Amy Lee. and Jenifer Bonner for mesocosm sampling assistance; David Huhman and Bonnie Watson for operating the elemental analysis; and Jennifer Black and Malay Saha for providing the clonal material used in this study.

\section{References}

Cassida KA, Muir JP, Hussey MA, Read JC, Venuto BC, Ocumpaugh WR. 2005. Biomass yield and stand characteristics of switchgrass in South Central U.S. environments. Crop Science 45: 673-681. ISSN 0011183X.

Chen S, van der Graaff E, Ytting NK, Thorup-Kristensen K. 2018. Evaluation of deep root phenotyping techniques in tube rhizotrons. Acta Agriculturae Scandinavica Section B: Soil and Plant Science 69: 62-74. ISSN 16511913.

De Mendiburu F, Simon R. 2015. Agricolae - Ten years of an open source statistical tool for experiments in breeding, agriculture and biology. PeerJ PrePrints 3: e1404v1. ISSN 2167-8359.

Duran BE, Duncan DS, Oates LG, Kucharik CJ, Jackson RD. 2016. Nitrogen fertilization effects on productivity and nitrogen loss in three grass-based perennial bioenergy cropping systems. PLOS ONE 11: e0151919. ISSN 19326203.

Ehleringer JR, Dawson TE. 1992. Water uptake by plants: perspectives from stable isotope composition. Plant, Cell \& Environment 15: 1073-1082. ISSN 13653040.

Foulkes MJ, Hawkesford MJ, Barraclough PB, Holdsworth MJ, Kerr S, Kightley S, Shewry PR. 2009. Identifying traits to improve the nitrogen economy of wheat: Recent advances and future prospects. Field Crops Research 114: 329-342. ISSN 03784290.

Freschet G, Pagès L, Iversen C, Comas L, Rewald B, Et A. 2020. A starting guide to root ecology: Strengthening ecological concepts and standardizing root classification, sampling, processing and trait measurements. Hal-02918834 : 291. 
bioRxiv preprint doi: https://doi.org/10.1101/2021.02.19.432036; this version posted February $22,2021$. The copyright holder for this preprint (which was not certified by peer review) is the author/funder, who has granted bioRxiv a license to display the preprint in

Freschet GT, Swart EM, Cornelissen JH. 2015. Integrated plant ${ }_{729}$ phenotypic responses to contrasting above- and below-730 ground resources: Key roles of specific leaf area and root ${ }_{731}$ mass fraction. New Phytologist 206: 1247-1260. ISSN $_{732}$ 14698137.

Gilley JE, Eghball B, Kramer LA, Moorman TB. 2000. Narrow 734 grass hedge effects on runoff and soil loss. Journal of Soil and ${ }_{735}$ Water Conservation 55: 190-196. ISSN 00224561.

Griffiths M, Seethepalli A, York LM. 2021. Data and statisti ${ }_{-737}$ cal analysis scripts for manuscript on switchgrass roots in ${ }_{738}$ nitrogen and water stresses [Data set].

Guo H, Ayalew H, Seethepalli A, Dhakal K, Griffiths $M, \mathrm{Ma}_{740}$ $\mathrm{XF}$, York LM. 2020. Functional phenomics and genetics ${ }_{741}$ of the root economics space in winter wheat using high $\neg_{42}$ throughput phenotyping of respiration and architecture. ${ }_{743}$ bioRxiv ISSN 26928205.

Guo H, York LM. 2019. Maize with fewer nodal roots allocates ${ }_{745}$ mass to more lateral and deep roots that improve nitrogen ${ }_{746}$ uptake and shoot growth. Journal of Experimental Botany ISSN $_{747}$ 14602431.

Heuermann D, Gentsch N, Boy J, Schweneker D, Feuerstein $U_{749}$ Groß J, Bauer B, Guggenberger G, von Wirén N. 2019. In-750 terspecific competition among catch crops modifies verti-751 cal root biomass distribution and nitrate scavenging in soils.752 Scientific Reports 9: 1-11. ISSN 20452322.

Hund A, Ruta N, Liedgens M. 2009. Rooting depth and wa -754 ter use efficiency of tropical maize inbred lines, differing ${ }_{755}$ in drought tolerance. Plant and Soil 318: 311-325. ISSN $_{756}$ $0032079 \mathrm{X}$.

Kristensen HL, Thorup-Kristensen K. 2004. Root Growth and 758 Nitrate Uptake of Three Different Catch Crops in Deep Soil ${ }_{759}$ Layers The method involves inserting transparent tubes. ${ }_{760}$ Soil Science Society of America Journal 68: 529-537.

Kumar K, Goh KM. 2002. Recovery of $15 \mathrm{~N}$-labelled fertilizer ${ }_{762}$ applied to winter wheat and perennial ryegrass crops and ${ }_{763}$ residual $15 \mathrm{~N}$ recovery by succeeding wheat crops under dif $_{764}$ ferent crop residue management practices. Nutrient Cycling 765 in Agroecosystems 62: 123-130. ISSN 13851314.

Kuznetsova A, Brockhoff PB, Christensen RHB. 2017. lmerTest 767 Package: Tests in Linear Mixed Effects Models . Journal of $f_{768}$ Statistical Software 82. ISSN 1548-7660.

Lai L, Kumar S, Osborne S, Owens VN. 2018. Switchgrass impact on selected soil parameters, including soil organic car- -771 bon, within six years of establishment. Catena 163: 288-296.772 ISSN 03418162.

Lemus R, Parrish DJ, Wolf DD. 2014. Switchgrass culti-774 var/ecotype selection and management for biofuels in the 775 upper southeast USA. Scientific World Journal 2014. ISSN $_{776}$ 1537744 X.

Lovell JT, MacQueen AH, Mamidi S. 2021. Genomic mecha 778 nisms of climate adaptation in polyploid bioenergy switch -779 grass. Nature .

Lowry DB, Lovell JT, Zhang L, Bonnette J, Fay PA, Mitchell RB, 781 Lloyd-Reilley J, Boe AR, Wu Y, Rouquette FM, Wynia RL,782 Weng X, Behrman KD, Healey A, Barry K, Lipzen A, Bauer D, Sharma A, Jenkins J, Schmutz J, Fritschi FB, Juenger TE. 2019. QTL $\times$ environment interactions underlie adaptive divergence in switchgrass across a large latitudinal gradient. Proceedings of the National Academy of Sciences of the United States of America 116: 12933-12941. ISSN 10916490.

Ma Z, Wood CW, Bransby DI. 2000. Impacts of soil management on root characteristics of switchgrass. Biomass and Bioenergy 18: 105-112. ISSN 09619534.

Ma Z, Wood CW, Bransby DI. 2001. Impact of row spacing, nitrogen rate, and time on carbon partitioning of switchgrass. Biomass and Bioenergy 20: 413-419. ISSN 09619534.

Milano ER, Lowry DB, Juenger TE. 2016. The genetic basis of upland/lowland ecotype divergence in switchgrass (Panicum virgatum). G3: Genes, Genomes, Genetics 6: 3561-3570. ISSN 21601836.

Morris GP, Grabowski P, Borevitz JO. 2011. Genomic diversity in switchgrass (Panicum virgatum): from the continental scale to a dune landscape. Molecular Ecology 20: 4938-4952.

Nagel KA, Putz A, Gilmer F, Heinz K, Fischbach A, Pfeifer J, Faget M, Blossfeld S, Ernst M, Dimaki C, Kastenholz B, Kleinert AK, Galinski A, Scharr H, Fiorani F, Schurr U. 2012. GROWSCREEN-Rhizo is a novel phenotyping robot enabling simultaneous measurements of root and shoot growth for plants grown in soil-filled rhizotrons. Functional Plant Biology 39: 891-904. ISSN 14454408.

Price DL, Casler MD. 2014. Inheritance of secondary morphological traits for among-and-within-family selection in upland tetraploid switchgrass. Crop Science 54: 646-653. ISSN $0011183 \mathrm{X}$.

R Core Team. 2020. R: A language and environment for statistical computing. $R$ Foundation for Statistical Computing . URL https://www.r-project.org/

Roley SS, Xue C, Hamilton SK, Tiedje JM, Robertson GP. 2019. Isotopic evidence for episodic nitrogen fixation in switchgrass (Panicum virgatum L.). Soil Biology and Biochemistry 129: 90-98. ISSN 00380717.

Saengwilai P, Nord EA, Chimungu JG, Brown KM, Lynch JP. 2014. Root cortical aerenchyma enhances nitrogen acquisition from low-nitrogen soils in maize. Plant Physiology 166: 726-735. ISSN 15322548.

Seethepalli A, York LM. 2020. RhizoVision Explorer - Interactive software for generalized root image analysis designed for everyone. Zenodo .

Singer E, Bonnette J, Kenaley SC, Woyke T, Juenger TE. 2019. Plant compartment and genetic variation drive microbiome composition in switchgrass roots. Environmental Microbiology Reports 11: 185-195. ISSN 17582229.

Venables WN, Ripley BD. 2002. Modern applied statistics with $S$. New York: Springer-Verlag, 4 edition. ISBN 0387954570.

Vogel KP. 1996. Energy production from forages (or American agriculture-Back to the future). Journal of Soil and Water Conservation 51: 137-139. ISSN 00224561.

Weaver J. 1954. North American Prairie. Johnsen Publishing.

Wei T, Simko V. 2017. R package "corrplot": Visualization of a Correlation Matrix (Version 0.84).

URL https://github.com/taiyun/corrplot

Ytting NK, Andersen SB, Thorup-Kristensen K. 2014. Using tube rhizotrons to measure variation in depth penetration rate among modern North-European winter wheat (Triticum aestivum L.) cultivars. Euphytica 199: 233-245. ISSN 15735060.

Yu P, Hochholdinger F, Li C. 2019. Plasticity of lateral root branching in maize. Frontiers in Plant Science 10: 363 . ISSN 1664462X.

Zhan A, Schneider H, Lynch JP. 2015. Reduced lateral root branching density improves drought tolerance in maize. Plant Physiology 168: 1603-1615. ISSN 15322548. 